\title{
PATHOGENS IN PROCESSED RAM SEMEN AND APPROACHES FOR THEIR ELIMINATION
}

\author{
Filipp Savvulidi' ${ }^{1}$, Martin Ptáček ${ }^{1}$, Luděk Stádník ${ }^{1}$ \\ ${ }^{1}$ Department of Animal Husbandry, Faculty of Agrobiology, Food and Natural Resources, Czech University of Life \\ Sciences Prague, Kamýcká 129, 16500 Prague - Suchdol, Czech Republic
}

\begin{abstract}
SAVVULIDI FILIPP, PTÁČEK MARTIN, STÁDNÍK LUDĚK. 2018. Pathogens in Processed Ram Semen and Approaches for Their Elimination. Acta Universitatis Agriculturae et Silviculturae Mendelianae Brunensis, 66(4): 1065-1072.

A variety of pathogenic contaminants might be isolated from semen, processed for artificial insemination (AI) programs: prions, viruses, bacteria, yeasts or protozoa. This review will discuss the broad scale of pathogens detected in processed ram semen. Reviewed findings will be confronted with the latest knowledge related to semen contamination in other livestock species. An accent will be placed on current experience and future aspects of approaches for elimination of pathogens from processed semen (especially, from semen processed under field conditions).
\end{abstract}

Keywords: ram semen, field conditions, artificial insemination, cryopreservation, contamination, antimicrobial peptides

\section{INTRODUCTION}

Artificial insemination (AI) is currently the most common and widespread reproductive biotechnology method facilitating genetic improvement by broad distribution of advantageous genes. Benefits of artificial insemination lies in reduced spread of disease by avoiding physical contact between animals during mating. This is ensured only if males used as semen donors are under strict health control (Cseh et al., 2012). Therefore, the newest version of the guidelines entitled "Collection and Processing of Bovine, Small ruminant and Porcine Semen" prepared by the World Organization of Animal Health (Terrestrial Animal Health Code, 2017a) provide detailed information and instructions on conditions applicable to testing males before entering an AI centre and general considerations for hygienic collection, handling and processing of semen.

However, it is not possible to test each ejaculate collected at AI center for the presence of pathogens. Further, asymptomatic males, infected with pathogens, were detected in AI centers (Prats-van der Ham et al., 2017). These asymptomatic males represent serious epidemiological risk regarding the transmission of the diseases. Thus, intensive use of AI may, paradoxically, increase the risk of spreading diseases or infectious agents across and within the flocks, since a wide range of pathogens may be shed in genital secretions of infected animals. Moreover, semen collection in livestock is not a sterile procedure. Fecal bacteria, preputial flora, respiratory secretions, and skin/hair may all act as potential sources of contamination for diluted semen; therefore, some degree of pathogens contamination cannot be fully avoided. For instance, ram semen is usually collected with an open-ended artificial vagina that may be contaminated with bacteria from the surface of the penis and prepuce, collection area, equipment or workers. As a consequence, pathogens might compromise the quality of collected semen and might contaminate the female's reproductive tract (Yániz et al., 2010). In addition, some potential contaminants (e.g. bacteria or mycoplasma) may be introduced into semen with animal-derived supplements used in semen diluents (egg yolk) (Bousseau et al., 1998). Pathogen-contaminated semen samples may result 
in substantial economic losses due to low fertility rates, abortion, and premature culling of breeding animals (Moustacas et al., 2010). So, whereas AI was initially set up to eliminate the problem of disease spread, the great caution must be maintained to ensure not to spread any infectious pathogens with AI (Philpott, 1993). Here is important to mention, that despite an enormous number of AI procedures carried out over the years, only a limited number of suspected disease transmissions have been reported (Cseh et al., 2012). This success is achieved partly due to the selection and maintenance of disease-free donor populations, as well as the high standards of collection procedures. On the other hand, the use of semen extenders supplemented with different combinations of antibiotics and several other approaches for elimination of pathogens from semen had undoubtedly contributed to this status (Cseh et al., 2012).

This review will discuss the broad scale of pathogens detected in processed semen of ram and other livestock species. An accent will be placed on current experience and future aspects of approaches for elimination of pathogens from processed semen. Special emphasis will be placed on most suitable approaches for elimination of pathogens from semen, processed under field (on-farm) conditions.

The methods of pathogens detection, the general questions of disease prevention management and the detailed diagnosis and clinical signs for reviewed diseases are all beyond the scope of this review and therefore should be found elsewhere.

\section{SEMEN CONTAMINATION WITH PRIONS}

Transmissible spongiform encephalopathy (scrapie) is a prion disease in sheep and goats, ranked in a same category as Creutzfeldt-Jakob disease in humans or bovine spongiform encephalopathy in cattle (Rubenstein et al., 2012). The main mode of disease transmission is from mother to offspring immediately after birth and to other susceptible neonates exposed to the birth fluids and tissues of an infected animal (Terrestrial Animal Health Code, 2017b). A hallmark of scrapie is the accumulation of an abnormally folded prion protein isoform prominently detected in the central nervous system; the consequence is the disruption of the nervous system, eventually resulting in death (Adams, 2016). Earlier researchers demonstrated that the transmission of prion disease did not occur with semen from infected rams, so it was concluded that the semen used in artificial insemination is an unlikely vector for prion disease transmission in sheep (Sarradin et al., 2008). However, a scrapie-positive ewes were found in a flock that had been scrapie-free for 13 years, but housed adjacent to scrapie-positive rams (Rubenstein et al., 2012). Authors hypothesized that these ewes may have been infected from scrapie-positive rams used for natural breeding, possibly through the semen.
The genotypes of the ewe flock were highly scrapie susceptible and the rams were infected with the "Caine" scrapie strain, which in such genotypes demonstrate very short incubation time. Using immunoassay with increased sensitivity for animal prion diseases, authors demonstrate that semen from rams infected with a short-incubation-time scrapie strain contains prion disease-associated seeding activity. These results suggest that the transmissible agent for sheep scrapie is present in ram semen (Rubenstein et al., 2012); nowadays, the general scientific opinion is inclined to think that the risk of scrapie infection via ram semen is not negligible; semen from scrapie-infected ram is thus confirmed as a hazard for the transmission of prion disease (Adams, 2016). In Czech sheep industry, the information about the scrapie susceptible genotype is a criterion for selecting animals in the subsequent breeding (Ptacek and Duchacek, in press).

\section{Approaches for prions elimination}

Due to nature of scrapie transmissible agent in ram semen, no approach for its elimination does exist. Rams should only enter an artificial insemination centre if they fulfill the requirements of scrapie-free status (Terrestrial Animal Health Code, 2017a). Additionaly, no evidence for reduced growth performance traits in relation to genetic resistance against scrapie disease for main Czech sheep meat breeds was detected in recent study by Ptacek and Duchacek (in press). Thus, the selection on genetic resistance against scrapie disease in sheep seems fully advantageous.

\section{SEMEN CONTAMINATION WITH VIRUSES AND BACTERIA}

Earlier researcher considered many viruses as potential threats through infected ram semen when AI: Foot-and-Mouth disease (FMD), rinderpest, sheep pox, Rift Valley fever, Wesselsbron disease, Border disease, Akabane virus, and Nairobi sheep disease (Philpott, 1993). Maedi-Visna virus, Bluetongue virus (BTV) and Peste des petits ruminants virus are listed in the newest version of the guidelines entitled "Collection and Processing of Bovine, Small ruminant and Porcine Semen" prepared by the World Organization of Animal Health as most relevant viruses that may be transmitted with ram semen (Terrestrial Animal Health Code, 2017a). Nevertheless, only FMD, BTV, Maedi-Visna, sheep pox and Border disease virus are currently relevant to European sheep industry. Disease transmission through infected ram semen used for AI is currently confirmed for FMD and for BTV (Thibier and Guerin, 2000).

Bacteria are present in every ejaculate and the aim of obtaining sterile semen is obviously non-achievable task. Bacteria can gain access to the semen as a result of bacteriaemia, due to local infections in parts of the genital tract or can be 
associated with blood cells or with inflammation or trauma of the urinary tract and the preputial cavity. Next source of semen bacterial contamination is the saprophytic flora of the prepuce in healthy semen donors, fecal bacteria, bacteria from substances of animal origin that are added to the semen diluents or from equipment and materials or workers and airborne bacteria (Thibier and Guerin, 2000; Bielanski, 2007).

A variety of bacteria have been isolated from ram semen: for instance, those causing ovine epididymitis (Brucella ovis, Actinobacillus seminis and Histophilus somni), infectious abortions (Coxiella burnetii) or ovine contagious agalactia (Mycoplasma agalactiae) (Saunders et al., 2007; Ruiz-Fons et al., 2014; Prats-van der Ham et al., 2016). Brucella ovis, the main cause of epididymitis in rams, can also cause abortion in ewes. Infection with Actinobacillus seminis is associated with epididymitis and reduced fertility in sexually immature rams. As Moustacas et al. (2010) have reviewed, Brucella ovis infection may result in reduction of pregnancy and lambing rates in ewes, in which vaginitis and salpingitis, as well as persistent mammary infection may also be observed. Abortions may also result from Actinobacillus seminis infection. Cases of ovine epididymitis due to Brucella ovis and Actinobacillus seminis infections have been reported in broad band of sheep-producing regions in the world (several European countries, NewZealand, Australia, South Africa, North America, and in various regions of South America). It is important to note, that chronically affected rams showing regression of lesions and clinical signs of epididymis are still able to shed the pathogen into their semen for prolonged intervals (Moustacas et al., 2010).

Yániz et al. (2010) has reported interesting results, performed on semen collected from apparently healthy and fertile rams. In their work, 66 from the 68 ejaculates were positive for aerobic bacteria with highest distribution of Escherichia coli, Proteus mirabilis, Enterobacter cloacae, Staphylococcus epidermis, and Staphylococcus aureus species. These commensal bacteria are also common in the semen of other species (Yániz et al., 2010). Because the semen came from healthy rams, authors supposed the main sources of bacterial contamination were the saprophytic bacteria of the prepuce or bacteria from the environment during the collection process. Importantly, it was demonstrated that the presence of enterobacterial species in semen was related to a reduced sperm quality during storage. The most negative effect on sperm quality was in the case of Escherichia coli, followed by Enterobacter cloacae, and Proteus mirabililis (Yániz et al., 2010).

\section{Approaches for viruses elimination}

Some viruses can adhere to the surface of spermatozoa, whereas others are associated with the seminal plasma or nonsperm cells present in the semen. Several reports have suggested an ability of some viruses (for instance, BTV) to penetrate the sperm head and to integrate their nuclei acid into the sperm genome; complete elimination of these viral agents from semen and sperm cells may be difficult or impossible (Bielanski, 2007).

It is well known, that semen washing and filtration (centrifugation, swim-up, fall down centrifugation, continuous and discontinuous Percoll gradients, albumin gradients, and glass bead and glass wool filtration) is helpful for reducing bacterial contaminants associated with semen. However, such a treatment will not generally eliminate the virus from infected semen with only few exceptions of effective elimination of the porcine reproductive and respiratory syndrome virus from infected boar semen and equine arteritis virus from experimentally infected equine semen, as reviewed by Bielanski (2007).

If the virus is not present inside the cytoplasm of the sperm (but rather associated with the sperm cell membrane), the trypsinization procedure may be helpful to reduce viral copies to undetectable levels or levels below clinical relevance. For instance, the human immunodeficiency virus, human hepatitis $C$ virus, and human hepatitis B virus were effectively eliminated from semen samples by using $0.25 \%$ trypsin incorporated into the density Percoll gradient centrifugation (Bielanski, 2007).

It was demonstrated, that transient semen acidification is a simple, quick and safe method for effective elimination of certain acid-labile viruses: BTV virus was inactivated just within $1 \mathrm{~min}$ below pH 6.0 and FMD virus has been shown to rapidly lose it's infectivity at pH 5.0 (Bielanski, 2007).

Immunoextenders, a promising method of inactivating of some viral agents from semen (Bielanski, 2007), contain neutralizing antibodies (immunoglobulins, Ig) to viruses. The Ig fraction proved to be most effective for inactivating BTV virus. There was no reactivation of the virus shown and no effect on the quality of the semen or on fertility. Moreover, the gamma globulin could be added to any of the common semen extenders. Antibodies, directly targeting the bacterial surface, can be possibly used to treat the semen for elimination of bacterial contamination. However, this approach is related to some limitations as antibodies to bacterial surface components rely on the recruitment of an array of antibody-directed immune effector functions. Drawbacks of antibodies to bacterial surface components are reviewed by Bebbington, Yarranton (2008).

\section{Approaches for bacteria elimination}

It is known, that the procedure of freezing-thawing itself may reduce the concentration of some common bacterial contaminants in semen (Bielanski, 2012). Nevertheless, the bacteria, possess a relatively high tolerance to the freezing procedure: the microbial contamination of cryopreserved semen stored for 6-35 years in liquid nitrogen was reported (Bielanski et al., 2003). For instance, Brucella ovis is highly resistant to cryopreservation as Moustacas et al. (2010) have 
reviewed. Therefore, several techniques were developed to minimize bacterial contamination in semen, employed in AI programs.

Dilution of the semen with sterile diluents will decrease the concentration of bacterial contaminants for some degree; however, this strategy is hardly applicable in ovine, as high sperm concentration is a demand in sheep AI.

Different colloid density centrifugation techniques are shown to be valuable for physical removal of bacteria from the semen; especially with the modification preventing the re-contamination of the sperm pellet during its extraction from the bottom of the centrifuge tube (Morrell and Wallgren, 2014). Authors declared these techniques as a relatively simple and easily applicable for most semen processing laboratories. From our point of view these techniques are not suitable for semen processing under field conditions (directly on the farm), as the access to centrifugation instrumentary is usually limited under field conditions.

Ozone treatment of semen might be used, as the ozone possesses bactericidal properties. The bactericidal effect (with minimal effect on sperm motility) was reported for ozone treatment to control Pseudomonas aeruginosa, Escherichia coli and Campylobacter fetus in experimentally contaminated bull semen (Gradil et al., 1995). However, this technique requires the system for ozone generation and/or distribution; moreover, the reported procedure of ozone treatment is time-consuming. Both these factors make the mentioned technique less applicable for the processing of semen under field conditions.

Enhance the hygienic measures during semen collection and processing will prevent semen contamination with bacteria (Yániz et al., 2010). However, it is unusual to find special sterility instrumentation (laminar air flow hoods, equipped with air-filters) at semen collection stations (Morrell and Wallgren, 2014). It is especially unusual to find these sterility instrumentation on the farm.

The effect of diode laser (DL) and light emitting diode (LED) red wavelengths irradiation on the bacterial contamination in bull semen was evaluated (Hussein et al., 2008). While clear negative impact of light exposure on spermatozoa viability in addition to the reduction of bacterial counts, certain wavelengths and exposure times were found to be optimum at reducing bacterial growth with a minimum effect on the sperm motility and viability (Hussein et al., 2008). Authors claimed, that AI in cattle can be improved safely through using DL and LED irradiation for reducting bacterial count while enhancing sperm motility. However, the red wavelengths irradiation improved the motility of ram spermatozoa to a small extent only (Zan-Bar et al., 2005). Moreover, the optimizing of wavelengths and exposure times to reduce the bacterial growth with a minimal negative effect on spermatozoa viability in ram semen is the task of future research.
So far, the most viable option to control the bacterial contamination in ram semen is using semen diluents containing compounds with bactericidal or bacteriostatic properties. This approach is especially valuable when semen collecting and processing under field condition.

For instance, the introduction of antibiotics to treat semen in vitro was one of the major stimulus to AI of dairy cattle. The Cornell extender, containing the antibiotic mixture of penicillin, streptomycin, and polymyxin B, was used for many decades as the standard for bull sperm (Foote, 2002). Early experimentation showed that these three antibiotics were not only effective for bacterial growth control in the diluted semen, but had no adverse effect on sperm viability, as reviewed by Bielanski (2007). The penicillin, streptomycin, sulfas, lincomycin, and gentamicin are the most frequently used antibiotics for livestock (Moustacas et al., 2010). For cryopreserved ram semen, the penicillin-streptomycin or (in a lesser extent) gentamicin was recommended as a routine tool to minimize the risk of transmitting Brucella ovis and Actinobacillus seminis (Moustacas et al., 2010). Penicillin is a b-lactam antibiotic, which inhibits the bacterial cell wall synthesis in multiplying bacteria; streptomycin and gentamicin bind to the 30 S ribosomal subunit and interfere with mRNA translation. The concentration of antibiotics is stipulated by the Council Directive 2003/43/EC of 26 May 2003 laying down the animal health requirements applicable to intra-Community trade in and imports of semen of domestic animals of the bovine species. According to this directive, not less than $500 \mu \mathrm{g}$ streptomycin, 500 IU penicillin, $150 \mu \mathrm{g}$ lincomycin and $300 \mu \mathrm{g}$ spectinomycin (or alternative combination of antibiotics with an equivalent effect) per milliliter of the final diluted semen must be used. As Morrell, Wallgren (2014) have reviewed, some antibiotics may be toxic to spermatozoa; and therefore, there is a tendency to use a cocktail of agents in semen extenders to reduce the negative effect of each individual component. However, it is known that even a small amount of antibiotic can result in the antibiotic resistence development. Indeed, many workers reported resistance to the antibiotics added to semen extenders for livestock animals (summarized by Morrell and Wallgren, 2014). So, the urgent need to find alternatives to conventional antibiotics for use in semen extenders exist.

The use of antimicrobial peptides (AMPs) has become one of the most promising alternatives to the use of antibiotics in semen extender's formulation to overcome the increasing bacterial resistance to antibiotics (Bussalleu et al., 2017). AMPs, positively charged polypeptides of up to 100 amino acids, act through destabilization of the bacterial cell membrane; no resistance development was demonstrated for AMPs (Morrell and Wallgren, 2014). While AMPs have the potential to serve as a new generation of antibiotics due to 
their broad-spectrum, rapid bactericidal activity and absence of resistance development, some particular AMPs at high concentrations have been shown to exert cytotoxic effects upon sperm (Bussalleu et al., 2017). Recently, different concentrations of three commercial AMPs (PR-39, PMAP-36, and PMAP-37) were tested to determine the possibility of replacing the common antibiotics without exhibiting negative effects upon boar sperm function and survival (Bussalleu et al., 2017). It was concluded, that the addition of commercial AMPs to semen is a suitable strategy to replace the use of antibiotics to control bacteriospermia, at least for PMAP-37. However, authors attentioned the dangers of detrimental effect of AMPs (PR-39 especially) on boar sperm motility and viability. This effect could be attributed to low level of cholesterol in the plasma membrane of boar spermatozoa, as it is known, that the presence of cholesterol in eukaryotic membranes reduces the potential cytotoxicity of AMPs (Bousseau et al., 1998). In this context, one should note that the cholesterol to phospholipid molar ratio in plasma membrane of ram spermatozoa is low, same as in boar (Holt, North, 1985). Therefore, there are good reasons for potential dangers of using antimicrobial peptides in ram semen due to possible deleterious effects upon spermatozoa. It might be interesting to test the combination of AMPs together with cyclodextrins, pre-loaded with cholesterol to determine whether AMPs could replace the common antibiotics in ram semen processing under field conditions. Cyclodextrins are cyclic oligosaccharide sugars, which are able to encapsulate and to transport the cholesterol into the sperm plasma membrane and by this to increase the cryoviability of sperm in ram, boar, bull and stallion, but not in rooster (where opposite effect to that expected on sperm motility and survival rates after cryopreservation was shown) as summarized by Partyka et al. (2018).

\section{SEMEN CONTAMINATION WITH YEASTS}

In livestock, yeasts have been implicated as causes of bovine reproductive problems, including abortion in cows and infertility in bulls, and equine uterine infections, as reviewed by Othman et al. (2016).

In general, yeasts possess a relatively low tolerance to the freezing procedure. In human semen, the proces of cryopreservation reduces the level of initial yeast contamination up to 10 times (Bielanski, 2012). However, commercially frozen bull semen samples were found to contain yeasts (Dion, 1979). Yeasts were generally members of the genera Candida. According to Dion (1979), contamination must have come from the use of a nonsterile extending fluid, as yeasts were found not to be a part of the natural flora in bovine semen. Importantly, Dion (1979) drew attention to the fact, that the contaminated commercially extended semen usually contained very few yeast cells. Despite this low contamination level, author recommended using only completely yeasts-free commercial preparations for semen diluting.

\section{Approaches for yeasts elimination}

Efficacy of different antimycotics in ram frozen semen extenders to treat yeasts was tested. It was shown, that many antimycotics can be harmful to the overall fertility of the spermatozoa. For instance, amphotricin-B and griseofulvin resulted in drastic deterioration of frozen spermatozoa quality in a dose-dependent manner, as summarized by Othman et al. (2016). However, addition of fluconazole to sheep semen diluent has a benefit of improving the quality of yeast contaminated sperm with no negative effect on the frozen-thawed semen quality as Othman et al. (2016) have recently demonstrated. Therefore, the suitability of, at least, some antimycotics to decrease yeasts contamination in processed ram semen might be concluded.

\section{SEMEN CONTAMINATION WITH PROTOZOA}

Protozoan parasites are a significant cause of abortion and infertility in domestic ruminants (Kaltungo and Musa, 2013). Toxoplasma gondii infection in sheep is distributed worldwide and is responsible for considerable economic losses. Toxoplasma gondii belongs to the phylum Apicomplexa and order Coccidia, and it is an obligate intracellular protozoan that affects various vertebrate hosts, including sheep (Lopes et al., 2013). Toxoplasma gondii infection can cause temporary impairment on the reproductive parameters of males as well as impairment of different hormones which may cause insufficient male reproductivity (Dalimi and Abdoli, 2013). In sheep, the sexual transmission of Toxoplasma gondii via infected ram semen was demonstrated (Lopes et al., 2013). Importantly, it was shown, that intrauterine contamination with tachyzoites of Toxoplasma gondii during artificial insemination can establish toxoplasmosis in ewes and cause reproductive pathologies, associated to the occurrence of embryonic death and reabsorption, fetaldeath and mummification, abortion, stillborn, and neonatal mortality, as summarized by Moraes et al. (2010). The process of sperm cryopreservation did not inhibit the infectious ability of tachyzoites of Toxoplasma gondii (Consalter et al., 2017).

Neospora spp., obligate intracellular parasite related to Toxoplasma gondii, has emerged as an important cause of reproductive disease, especially as an abortifacient in cattle (Kaltungo and Musa, 2013; Syed-Hussain et al., 2013). In sheep, the first natural infection of Neospora caninum was identified in 1990 in a congenitally infected lamb with signs of ataxia and weakness after birth; repeated abortions in subsequent years have also been reported. Naturally occurring ovine neosporosis has been reported worldwide, 
including Europe, South America, Australia and New Zealand (Syed-Hussain et al., 2013). In bovine, the transmission of Neospora caninum via semen was thought to be possible as bulls were found to be seropositive towards Neospora caninum and Neospora caninum DNA was detected in the semen of naturally and experimentally infected bulls. Dose dependent seroconversion and parasitaemia were also seen in heifers inseminated with semen spiked with Neospora caninum tachyzoites, though no seroconversion or detection of $N$. caninum DNA in the embryo or calves was observed (Syed-Hussain et al., 2013). In ovine, the presence of Neospora caninum DNA in the semen of experimentally infected rams was also determined; this would suggest the possibility of transmission of Neospora caninum via the venereal route. Nevertheless, the degree which Neospora caninum transmission occurs through AI remains to be determined. Earlier research just concluded, that the transmission of Neospora caninum via ram semen is an unlikely during natural mating. This is because no evidence for transmission of Neospora caninum to naturally mated ewes were obtained (Syed-Hussain et al., 2013).

\section{Approaches for protozoa elimination}

For Toxoplasma gondii elimination, infected semen might be possibly treated in vitro with the combination of several anti-Toxoplasma drugs (pyrimethamine, sulfadiazine and folinic acid or trimethoprim/sulfamethoxazole), same as for in vivo treatment of infected patients or animals (Syed-Hussain et al., 2013). However, it was shown, that anti-Toxoplasma drugs (particularly pyrimethamine), might have adverse effects on male reproductive function: sperm motility and sperm concentration were significantly decreased in pyrimethamine treated animals (Syed-Hussain et al., 2013). Therefore, the semen collection and processing for AI should be avoided from rams without Toxoplasma gondii-free status.

\section{CONCLUSION}

A variety of pathogenic contaminants might be isolated from processed ram semen: prions, viruses, bacteria, yeasts or protozoa. Among these, bacterial contamination of processed semen is mostly presumptive, as bacteria are present in every ejaculate and the aim of obtaining sterile semen is non-achievable task. Bacteria possess a relatively high tolerance to the cryopreservation procedure. The presence of bacterial species in semen is related to a reduced sperm quality. Therefore, several techniques were developed to minimize bacterial contamination in semen, employed in AI programs, but the most viable option to control the bacterial contamination is to use of semen diluents containing antibiotics or other compounds with bactericidal properties. The use of antimicrobial peptides (AMPs) has become promising alternative to the use of antibiotics in semen extender's formulation to overcome the increasing bacterial resistance to antibiotics. However, the dangers of detrimental effect of AMPs upon spermatozoa were reported. This could be attributed to low level of cholesterol in the plasma membrane of spermatozoa, as it is known, that the presence of cholesterol in eukaryotic membranes reduces the potential cytotoxicity of AMPs. On this matter, it will be interesting to test the combination of AMPs together with cyclodextrins, pre-loaded with cholesterol, to determine whether AMPs could replace the common antibiotics in ram semen processing under field conditions.

\section{Acknowledgments}

This work was supported by S grant of Ministry of Education, Youth and Sport (MEYS) of Czech Republic.

\section{REFERENCES}

ADAMS, D. B. 2016. Prenatal transmission of scrapie in sheep and goats. A case study for veterinary public health. Open Vet. J., 6(3): 194-214.

BEBBINGTON, C. and YARRANTON, G. 2008. Antibodies for the treatment of bacterial infections. Current experience and future prospects. Curr. Opin. Biotechnol., 19(6): 613-619.

BIELANSKI, A., BERGERON, H., LAU, P. C. K. and DEVENISH, J. 2003. Microbial contamination of embryos and semen during long term banking in liquid nitrogen. Cryobiology, 46(2): 146-152.

BIELANSKI, A. 2007. Disinfection procedures for controlling microorganisms in the semen and embryos of humans and farm animals. Theriogenology, 68(1): 1-22.

BIELANSKI, A. 2012. A review of the risk of contamination of semen and embryos during cryopreservation and measures to limit cross-contamination during banking to prevent disease transmission in ET practices. Theriogenology, 77(3): 467-482.

BOUSSEAU, S., BRILLARD, J. P., MARGUANT-LE GUIENNE, B., GUÉRIN, B., CAMUS, A. and LECHAT, M. 1998. Comparison of bacteriological qualities of various egg yolk sources and the in vitro and in vivo fertilizing potential of bovine semen frozen in egg yolk or lecithin based diluents. Theriogenology, 50(5): 699-706.

BUSSALLEU, E., SANCHO, S., BRIZ, M., YESTE, M. and BONET, S. 2017. Do antimicrobial peptides PR-39, PMAP-36 and PMAP-37 have any effect on bacterial growth and quality of liquid-stored boar semen? Theriogenology, 89: 235-243. 
CONSALTER, A., SILVA, A., FRAZÃO-TEIXEIRA, E., MATOS, L., DE OLIVEIRA, F., LEITE, J., SILVA, F. and FERREIRA A. 2017. Toxoplasma gondii transmission by artificial insemination in sheep with experimentally contaminated frozen semen. Theriogenology, 90(1): 169-174.

COUNCIL OF THE EUROPEAN UNION. 2003. Council Directive 2003/43/EC of 26 May 2003 laying down the animal health requirements applicable to intra-Community trade in and imports of semen of domestic animals. Available at: http://eur-lex.europa.eu/legal-content/EN/TXT/?uri=CELEX:32003L0043. [Accessed: 2018, May 18].

CSEH, S., FAIGL, V. and AMIRIDIS, G. S. 2012. Semen processing and artificial insemination in health management of small ruminants. Anim. Reprod. Sci., 130 (3-4): 187-192.

DALIMI, A. and ABDOLI, A. 2013. Toxoplasma gondii and Male Reproduction Impairment. A new Aspect of Toxoplasmosis Research. Jundishapur. J. Microbiol., 6(8): e7184.

DION, W. M. 1979. The origin and species of yeasts in commercial preparations of bovine semen. Can. J. Comp.Med., 43(1): 16-21.

FOOTE, R. H., 2002. The history of artificial insemination: Selected notes and notables. J. Anim. Sci., 80(E-Suppl_2): 1-10.

GRADIL, C., EAGLESOME, M. D., STEWART, B., GARCIA, M. M. and QUIMBY, F. 1995. Bactericidal effects of ozone at nonspermicidal concentrations. Can. J. Vet. Res., 59(3): 183-186.

HOLT, W. V. and NORTH, R. D. 1985. Determination of lipid composition and thermal phase transition temperature in an enriched plasma membrane fraction from ram spermatozoa. J. Reprod. Fertil., 73(1): $285-294$.

HUSSEIN, Z., EL-TAYEB, T., EL-KERABY, F. and HARITH, M. 2008. The effect of diode laser and light emitting diode on the bacterial contamination of semen medium for artificial insemination. Biologicals, 36(5): 303-307.

KALTUNGO, B. Y. and MUSA, I. W. 2013. A Review of Some Protozoan Parasites Causing Infertility in Farm Animals. ISRN Trop.Med., 2013(3): 1-6.

LOPES, W. D. Z., RODRIGUEZ, J. D., SOUZA, F. A., DOS SANTOS, T. R., DOS SANTOS, R. S., ROSANESE, W. M., LOPES, W. R.Z., SAKAMOTO, C. A. and DA COSTA, A. J. 2013. Sexual transmission of Toxoplasma gondii in sheep. Vet. Parasitol., 195(1-2): 47-56.

MORAES, E. P. B. X., FREITAS, A. C., GOMES-FILHO, M. A., GUERRA, M. M. P., SILVA, M. A. R., PEREIRA, M. F., BRAGA, V. A. and MOTA, R. A. 2010. Characterization of reproductive disorders in ewes given an intrauterine dose of Toxoplasma gondii tachyzoites during the intrauterine insemination. Anim. Reprod. Sci., 122(1-2): 36-41.

MORRELL, J. and WALLGREN, M. 2014. Alternatives to antibiotics in semen extenders. A review. Pathogens, 3(4): 934-946.

MOUSTACAS, V. S., XAVIER, M. N., CARVALHO-JÚNIOR, C. A., COSTA, E. A., HENRY, M. and SANTOS, R. L. 2010. Effect of extender supplementation with various antimicrobial agents on viability of Brucella ovis and Actinobacillus seminis in cryopreserved ovine semen. Theriogenology, 74(8): 1476-1481.

OTHMAN, F. M., EL BADRY, D. A., MOHAMED, M. I., SHAKER, M. H., KOTB, H. R. and TORKY, H. A. 2016. Efficacy and Safety of Different Antimycotic Formulas Used in Sheep Frozen Semen Extenders. Alexandria J.Vet. Sci., 48(2): 77.

PARTYKA, A., STROJECKI, M. and NIŻAŃSKI, W. 2018. Cyclodextrins or cholesterol-loaded-cyclodextrins? A better choice for improved cryosurvival of chicken spermatozoa. Anim. Reprod. Sci., 193: 235-244.

PHILPOTT, M., 1993. The dangers of disease transmission by artificial insemination and embryo transfer. Br. Vet. J., 149(4): 339-369.

PRATS-VAN DER HAM, M., TATAY-DUALDE, J., DE LA FE, C., PATERNA, A., SÁNCHEZ, A., CORRALES, J. C., CONTRERAS, A. and GÓMEZ-MARTÍN, Á. 2016. Presence of Mycoplasma agalactiae in semen of naturally infected asymptomatic rams. Theriogenology, 86(3): 791-794.

PRATS-VAN DER HAM, M., TATAY-DUALDE, J., DE LA FE, C., PATERNA, A., SÁNCHEZ, A., CORRALES, J. C., CONTRERAS, A. and GÓMEZ-MARTÍN, Á. 2017. Detecting asymptomatic rams infected with Mycoplasma agalactiae in ovine artificial insemination centers. Theriogenology, 89: 324-328.

PTACEK, M. and DUCHACEK, J. 2018 Genetic resistence against scrapie disease related to lamb growth performance traits. Sci. Agric. Bohem., in press

RUBENSTEIN, R., BULGIN, M., CHANG, B., SORENSEN-MELSON, S., PETERSEN, R. and LA FAUCI, G. 2012. PrP(Sc) detection and infectivity in semen from scrapie-infected sheep. J. Gen. Virol., 93(6): 1375-1383. RUIZ-FONS, F., GONZÁLEZ-BARRIO, D., AGUILAR-RÍOS, F., SOLER, A., GARDE, J., GORTÁZAR, C. and FERNÁNDEZ-SANTOS, M. 2014. Infectious pathogens potentially transmitted by semen of the black variety of the Manchega sheep breed. Health constraints for conservation purposes. Anim. Reprod. Sci., 149(3-4): 152-157.

SARRADIN, P., MELO, S., BARC, C., LECOMTE, C., ANDRÉOLETTI, O., LANTIER, F., DACHEUX, J.-L. and GATTI, J.-L. 2008. Semen from scrapie-infected rams does not transmit prion infection to transgenic mice. Reproduction, 135(3): 415-418.

SAUNDERS, V.F., REDDACLIFF, L. A., BERG, T. and HORNITZKY, M. 2007. Multiplex PCR for the detection of Brucella ovis, Actinobacillus seminis and Histophilus somni in ram semen. Aust. Vet. J., 85(1-2): 72-77. 
SYED-HUSSAIN, S. S., HOWE, L., POMROY, W. E., WEST, D. M., SMITH, S. L. and WILLIAMSON, N. B. 2013. Detection of Neospora caninum DNA in semen of experimental infected rams with no evidence of horizontal transmission in ewes. Vet. Parasitol., 197(3-4): 534-542.

TERRESTRIAL ANIMAL HEALTH CODE. 2017a. Collection and processing of bovine, small ruminant and porcine semen, Chapter 4.6. [Online.]. Available at: http://www.oie.int/index.php?id=169\&L=0\&htmfile=chapitre coll_semen.htm [Accessed:2018, May 18].

TERRESTRIAL ANIMAL HEALTH CODE. 2017b. Scrapie, Chapter 14.8. [Online.]. Available at: http://www. oie.int/index.php?id=169\&L=0\&htmfile=chapitre_scrapie.htm [Accessed: 2018, May 18].

THIBIER, M. and GUERIN, B. 2000. Hygienic aspects of storage and use of semen for artificial insemination. Anim. Reprod. Sci., 62(1-3): 233-251.

YÁNIZ, J., MARCO-AGUADO, M., MATEOS, J. and SANTOLARIA, P. 2010. Bacterial contamination of ram semen, antibiotic sensitivities, and effects on sperm quality during storage at $15^{\circ} \mathrm{C}$. Anim. Reprod. Sci., 122(1-2): 142-149.

ZAN-BAR, T., BARTOOV, B., SEGAL, R., YEHUDA, R., LAVI, R., LUBART, R. and AVTALION, R. R. 2005. Influence of visible light and ultraviolet irradiation on motility and fertility of mammalian and fish sperm. Photomed. Laser Surg., 23(6): 549-555.

Filipp Savvulidi: fsavvulidi@gmail.com Martin Ptáček: ptacekm@af.czu.cz Luděk Stádník: stadnik@af.czu.cz 